\title{
Novel antibodies against RCD-8 as a tool to study processing bodies
}

\author{
D. O. Gudkova ${ }^{1,2}$, G. G. Panasyuk ${ }^{1}$, I. O. Nemazanyy ${ }^{1}$, V. V. Filonenko ${ }^{1}$ \\ ${ }^{1}$ Institute of Molecular Biology and Genetics NAS of Ukraine \\ 150, Akademika Zabolotnoho Str., Kyiv, Ukraine, 03680 \\ ${ }^{2}$ Taras Shevchenko Kyiv National University \\ 64, Volodymyrska Str., Kyiv, Ukraine, 01033 \\ filonenko@imbg.org.ua
}

\begin{abstract}
Aim. To develop the model system for processing bodies (PBs) state monitoring and accomplish it in the future as a possible read-out of mTOR activity in mammalian cells. Methods. In course of this study we raised polyclonal antibodies against one of the PBs scaffold proteins $-R C D-8$ and employed cell imaging technique. Results. It has been shown that the obtained antibodies recognize the intracellular structures, namely PBs. The detected protein co-localized with known marker of PBs-DCP1a, and partly with marker of SGs-CPEB. Conclusions. Based on changes of PBs number and size in cells after exposure to known inductors or inhibitors of $P B$ formation we prove the specificity of generated antibodies and possibility of their application for studies on the processing bodies dynamics controlled by mTOR-dependent signaling.
\end{abstract}

Key words: mRNA processing, decapping, processing bodies, immunocytochemistry.

Introduction. Nascent mRNA transcripts are modified co-transcriptionally at their $5^{\prime}$ end with 7-methylguanosine $\left(\mathrm{m}^{7} \mathrm{G}\right)$ cap and $3^{\prime}$ end by adding adenylic nucleotides to form poly(A) tail [1]. The cap structure is absolutely necessary for accomplishment of mRNA functions and is involved in RNA processing (through activation of formation of poly(A) tail and promoting pre-mRNA splicing), translation initiation, protection of mRNA from $5^{\prime} \rightarrow 3^{\prime}$ cleavage, etc. [2, 3]. There is well known and studied interaction between the translation initiation components and cap itself during translation. With no direct involvement in the cap metabolism, these proteins protect the cap structure from degradation sterically by preventing nucleases from accessing this region of mRNA. From the other hand, the

(C) Institute of Molecular Biology and Genetics NAS of Ukraine, 2010 $\mathrm{m}^{7} \mathrm{G}$ cap itself prevents exonucleolytic degradation of mRNA; thus, its removal triggers rapid and complete degradation of mRNA. This process is known as decapping and it is irreversible in contrast to deadenylation $[1,4]$.

The precise mechanism of decapping control is unknown, however, according to a proposed model the decapping rate is controlled by a steric competition for the cap structure between the decapping enzyme and the translation initiation machinery. When the cap binding protein, eIF4E (eukaryotic translation initiation factor $4 \mathrm{E}$ ), is bound to the cap structure, mRNA decapping is blocked. Dissociation of eIF4E from the cap structure is a key step in facilitating decapping [5]. The formation of translational initiation complex on the cap structure also depends on the phosphorylation status of eIF4E binding proteins (4E-BPs) which bind to eIF4E 
and prevent its association with eIF4G thereby inhibiting the cap-dependent translation of mRNA [6].

4E-BPs are well characterized downstream effectors of PI3K/mTOR signaling pathway. It is known that the phosphorylation of S6Ks and 4E-BPs by mTOR regulates the rate of translation initiation in response to diverse extracellular stimuli, such as growth factors, mitogenes and nutrients $[5,7]$.

The assembly of translationally active cap-binding eIF4F complex is controlled by the state of 4E-BP1 phosphorylation mediated by the mTOR signaling pathway. It is logical to speculate that formation of the cap-dependent translation initiation complex may affect the rate of mRNA translation through a block of decapping of these matrices. PI3K/mTOR signaling pathway may regulate mRNA translation through phosphorylation of 4E-BPs and in this way decrease decapping activity (accordingly to a model of steric competition for binding to the cap).

In mammalian cells, a pool of nontranslating mRNAs can be accumulate in two types of cytoplasmic mRNP granules: processing bodies (PB), which generally contain the mRNA decay machinery and stress granules (SG), which contain a set of proteins, involved in the translation initiation including $40 \mathrm{~S}$ ribosomal subunit [3]. The recent data suggest that PBs are involved in the cytoplasmic processing of mRNA and play a critical role in mRNA degradation and post-transcriptional gene silencing $[8,9]$.

One of the specific scaffold proteins of PBs is RCD8 (also known as Ge-1, EDC-4). Using human sera screening it was first identified as autoantigen [10-12]. In cells RCD-8 was shown to co-localize with previously identified PB components, including proteins, involved in mRNA decapping (DCP1a and DCP2), and the autoantigen GW182 [12]. An exact role of RCD-8 is not clear yet, but there are several observations indicating that RCD- 8 might be a scaffold protein for the decapping machinery and can promote the interaction between hDCP1 and hDCP-2 [13]. Down regulation of RCD-8 in the cell by siRNA-mediated knock-out prevents DCP1a and DCP2 from accumulating in PBs and affects mRNA degradation [12].

The aim of current work was to develop a model system for PBs monitoring (possible changes in PBs number and/or size) by employing cell imaging tech- nique and conduct it in future as a possible read-out of the mTOR/PI3K signaling activity in mammalian cells.

Materials and Methods. Production and purification offusion protein. cDNA of RCD-8 was kindly provided by Dr. Ivan Gout (UCL, UK). A cDNA fragment corresponding to 1-150 aa of human RCD-8 was cloned into $p E T 24 a$ vector in frame with the N-terminal 6His-GST tag («Novagen», USA). pET24a- His-RCD-8 was then transformed into BL21DE3 Escherichia coli strain. The expression of recombinant proteins was induced with $1 \mathrm{mM}$ isopropyl- $\beta$-D-(2)-thiogalactopyranoside (IPTG) for $5 \mathrm{~h}$ at $30^{\circ} \mathrm{C}$. Affinity purification of recombinant His-RCD-8 from bacteria cell lysates was carried out on Ni-NTA agarose («Qiagen», USA) according to the manufacturer's recommendations. The purity of the fusion proteins was confirmed by sodium dodecyl sulfate-polyacrylamide gel electrophoresis (SDS-PAGE).

Plasmids and antibodies. Plasmids, encoding RFPDCP and GFP-CPEB were kindly provided by Dr. Dominique Weil. Rabbit anti-RCD-8 antibodies were obtained from Bethyl Laboratories. Anti-mouse FITCconjugated antibodies were from Jackson ImmunoResearch Laboratories. Anti-mouse Texas Red-conjugated antibodies were from «Invitrogen» (USA). Secondary HRP-labelled anti-mouse and anti-rabbit antibodies were from «Cell Signaling» (USA).

Cell culture and immunocytochemistry. HEK293 cells were obtained from the American Type Culture Collection and maintained in DMEM supplemented with $10 \%$ fetal bovine serum («HyClone», UK), penicillin $(200 \mathrm{U} / \mathrm{ml})$ and streptomycin $(200 \mathrm{mg} / \mathrm{ml})$. To induce PBs assembly/disassembly HEK293 cells were exposed to sodium arsenite (III) $(0.5 \mathrm{mM})$ or puromycin $(25 \mu \mathrm{g} / \mathrm{ml})$ or CHX $(50 \mu \mathrm{g} / \mathrm{ml})$ for $0.5 \mathrm{~h}$ at $37^{\circ} \mathrm{C}$. All reagents were obtained from «SIGMA» (USA). For immunofluorescent staining HEK293 cells were grown in tissue culture chambers («Nunc», Denmark), fixed with $3.7 \%$ paraformaldehyde in PBS, and permeabilized with PBS-T $(0.2 \%$ Tween-20) three times for $5 \mathrm{~min}$. Unspecific binding was blocked by $45 \mathrm{~min}$ incubation of cells with $5 \%$ FBS diluted in PBS-T. Afterwards staining with primary and secondary antisera was performed as described previously [11]. Transfections were carried out in 24 well plates using $2 \mu \mathrm{g}$ of DNA and JetPEI reagent («PolyPlus», France) 
as manufacturer recommended. 24 hours after transfection cells were fixed and stained with anti-RCD-8 antibodies. Fluorescently labelled cells were viewed with a Zeiss LSM Meta 510 confocal microscope, and the images were analyzed using the LSM510 image browser software.

SDS-PAGE, Western blotting. HEK293 or E. coli cell protein extracts were resolved in SDS-polyacrylamide gels and transferred to PVDF membranes. Membranes were incubated in blocking solution and probed with rabbit anti-RCD-8 (1:5000) antibodies diluted in $25 \mathrm{mM}$ Tris- $\mathrm{HCl}$ (pH 7.4), $0.8 \% \mathrm{NaCl}, 0.02 \% \mathrm{KCl}$, and $0.05 \%$ Tween (TBST). Immune complexes were detected using HRP-labelled anti-rabbit antibodies.

Immunoprecipitation. HEK293 cells were washed twice with ice-cold PBS and then lysed using lysis buffer EB $(150 \mathrm{mM} \mathrm{NaCl}, 50 \mathrm{mM}$ Tris, pH7.5, $0.5 \mathrm{mM}$ EDTA, $0.5 \mathrm{mM} \mathrm{NaF}, 0.5 \%$ Triton X-100, Coctail of protease inhibitors). After incubation for $30 \mathrm{~min}$ on ice the lysate was centrifuged for $15 \mathrm{~min}$ at $13,000 \times \mathrm{g}$. Supernatant was incubated with anti RCD-8 antibodies and protein A-sepharose («GE Healthcare», UK). Then beads were washed four times with EB buffer. Next, immunoprecipitates and total protein extracts were resolved by SDS-PAGE and transferred to PVDF membranes («Millipore», USA). The membrane was blocked with $5 \%$ skim milk in TBST for $1 \mathrm{~h}$, and then incubated with anti-RCD-8 antibodies. After washing three times with TBST the membrane was incubated with HRP-conjugated goat anti-rabbit IgG («Promega», USA). Finally, the membrane was developed using an ECL kit («GE Healthcare») and then exposed to Agfa X-ray film. Non-specific binding of RCD-8 to sepharose beads was analyzed in samples without antibodies.

Results and Discussion. To generate anti-RCD8 antibodies a fragment of RCD-8 corresponding to 1150 aa was used as an antigen for mice immunization. Recombinant His-RCD-8 was expressed in E. coli cells and purified using Ni-NTA-agarose, as recommended by the manufacturer. Using a standard scheme of immunization with boosting mice every 2 weeks, a titer of nearly 105 of anti-RCD- 8 antibodies in the serum of the immunized mice was achieved on the 45th day of immunization.

Polyclonal anti-RCD-8 antibodies were affinity purified from polyclonal ascite fluid using antigen accor-

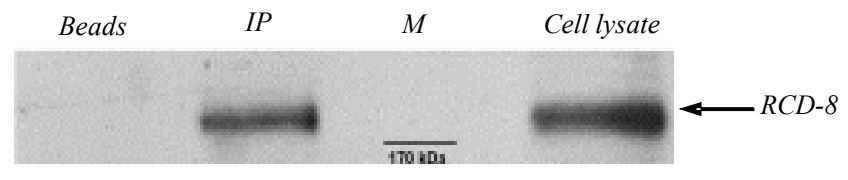

Fig. 1. Immunoprecipitation of endogenous RCD-8 from HEK293 cell lysate. Supernatant was incubated with anti-RCD-8 antibodies and protein A-sepharose. Immune complexes were analyzed by immnunoblotting using anti-RCD-8 (Bethyl Laboratories) antibodies. Non-specific binding of RCD-8 to sepharose beads was analyzed in sample without antibodies

ding to the standard protocol [14]. The specificity of purified antibodies was analyzed by immunoprecipitation of endogenous RCD-8 from HEK293 cell lysate (Fig. 1) and by Western blot analysis of HEK293 cell lysate with overexpressed recombinant HA-tagged RCD-8 (data not shown).

Next, we tested whether the obtained affinity purified anti-RCD-8 antibodies could detect RCD-8 in PBs of mammalian cells. For this, we employed immunofluorescense approach using different mammalian cell lines (HEK293, MCF-7, HeLa, U2OS). We were able to detect some discrete structures in all cell lines, particularly in HEK293 (Fig. 2, see inset). Number of these structures varied depending on cells type (data not shown), which is in good agreement with previous observations $[8-13,15,16]$. To check whether these structures are PBs we overexpressed the markers of PBs and SGs fused with fluorescent proteins (DCP1- RFP- or CPEB-GFP correspondently) in HEK293 cells. Using confocal microscopy we were able to confirm colocalization of DCP1-RFP with structures detected by generated anti-RCD-8 antibodies. In this way we confirmed the specificity of purified antibodies with respect to PB (Fig. 3, see inset). Partial merge of signals obtained from anti-RCD-8 antibodies and CPEB-GFP could be explained by physical association between PBs and SGs, because CPEB is a known inductor of SG in the cells $[15,16]$ (Fig. 4, see inset).

According to the presented data, RCD-8 is localized only in PB but we can't exclude the presence of RCD-8 in other sites where its content is lower.

Next we verified the specificity of anti-RCD-8 antibodies using well known agents that promote assembly/disassembly of PBs. According to the previously published data the treatment of mammalian cells with cycloheximide (which inhibits translation elongation 
Figures to article by D. O. Gudkova et al.
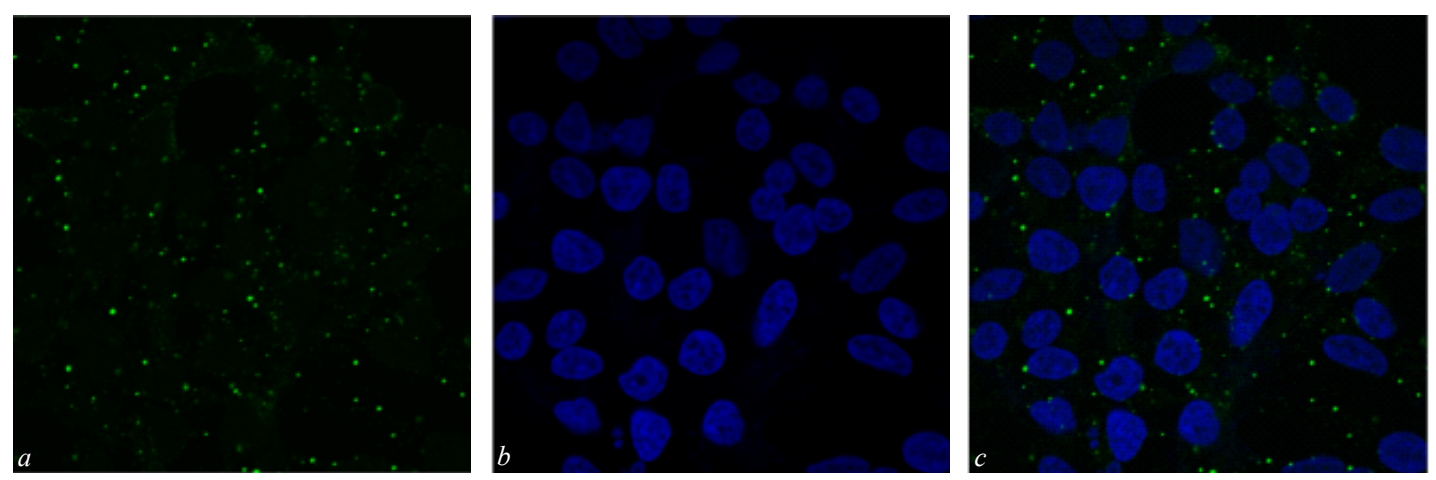

Fig. 2. Processing bodies in HEK293 cells. Cells were fixed with $3.7 \%$ FA and stained with a-RCD-8 antibodies (ab) $(a)$. As secondary FITC-conjugated anti-mouse ab were used. Nuclei $(b)$ were stained with Hoechst. Picture $c$ represents a merge of signals. $\times 100$
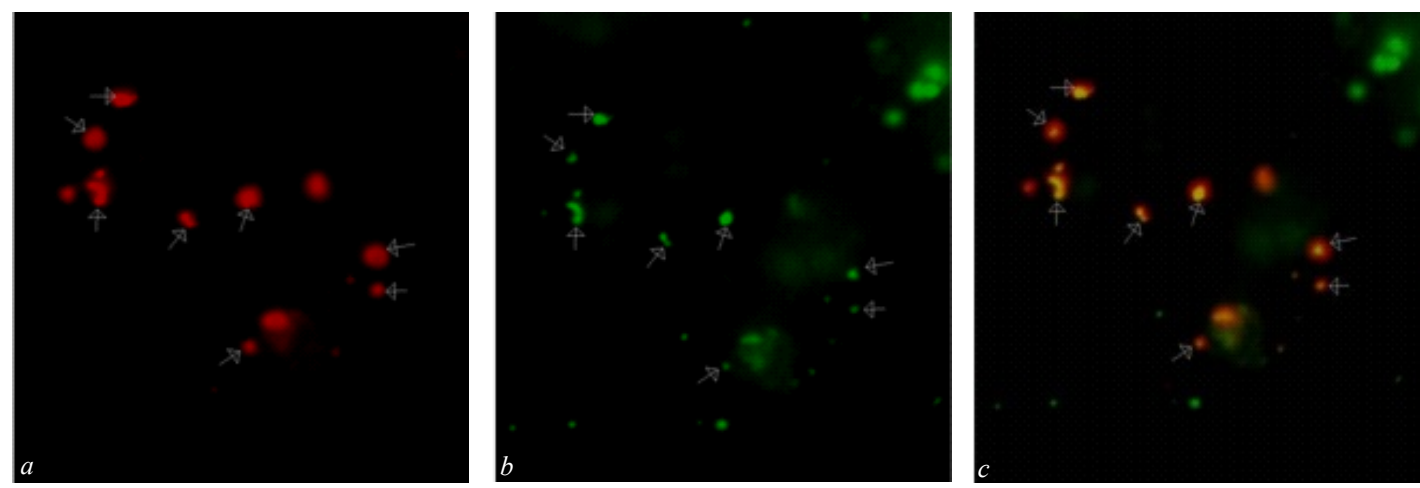

Fig. 3. Discrete foci are co-localized with known marker of processing bodies - DCP1a. HEK293

cells were transfected with DCP- RFP $(a)$. After $24 \mathrm{~h}$ cells were fixed with $3.7 \% \mathrm{FA}$ and stained with a-RCD-8 antibodies (ab) (b). As secondary FITCconjugated anti-mouse $a b$ were used. Picture $c$ represents a merge of signals. $\times 100$
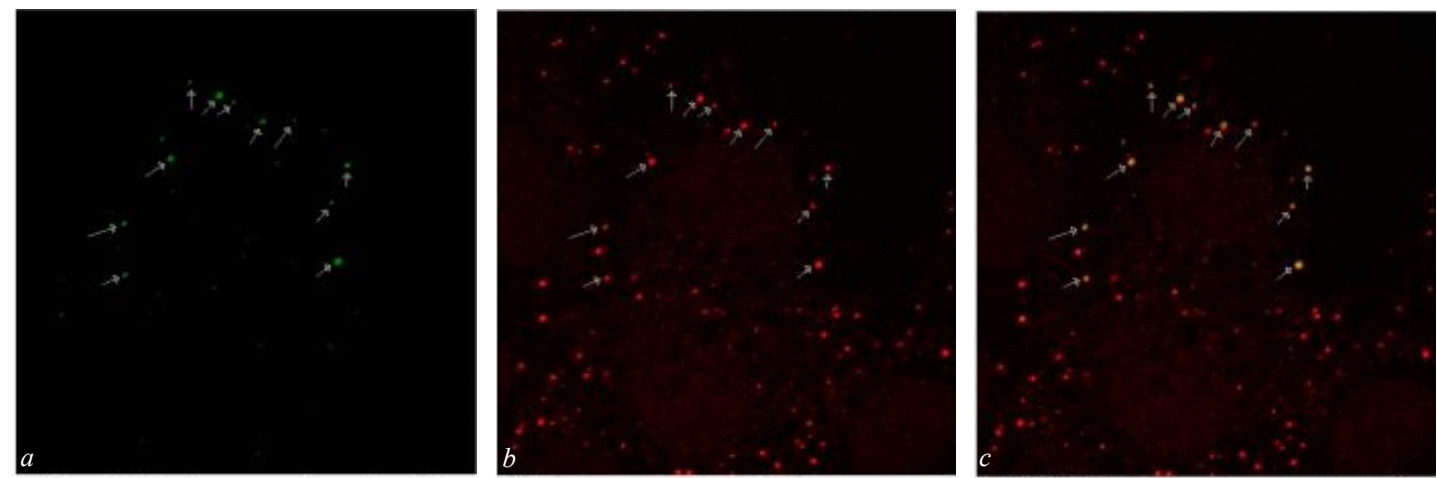

Fig. 4. Discrete foci are partly co-localized with known marker of stress granules - CPEB. HEK293 cells were transfected with CPEB-GFP $(a)$. In a day they were fixed with $3.7 \%$ FA and stained with a-RCD-8 antibodies (ab) (b). As secondary Texas Red-conjugated anti-mouse ab were used. Picture $c$ represents a merge of signals. $\times 100$
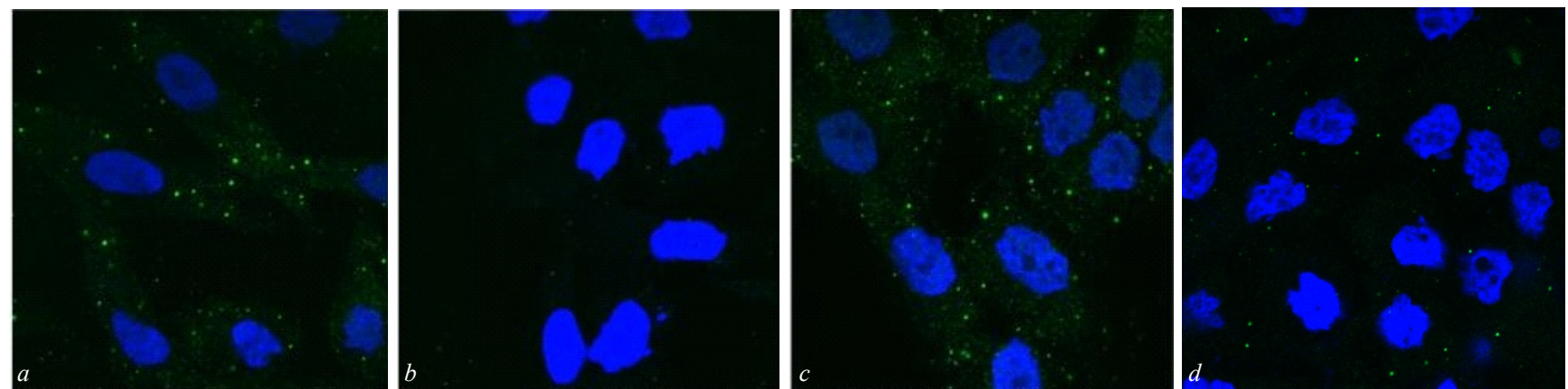

Fig. 5. HEK 293 cells were treated with sodium arsenite $0.5 \mathrm{mM}(a)$, cycloheximide $50 \mu \mathrm{g} / \mathrm{ml}(b)$ and puromycin $25 \mu \mathrm{g} / \mathrm{ml}(c)$ during $30 \mathrm{~min}$. Picture $d$ represents untreated cells. Then cells were fixed with 3.7\% FA and stained with a-RCD-8 antibodies (ab). As secodary FITC-conjugated anti-mouse ab were used. Nuclei were stained with Hoechst. $\times 100$ 
and traps mRNAs on polysomes) decreases the flow of mRNA to PBs and causes rapid loss of these foci [11]. Conversely, some drugs (e. g. puromycin) release mRNA from ribosomes resulting in an increase of PBs number and size and making mRNA available to decapping machinery $[3,16]$. Arsenite is also a known inductor of PBs in mammalian cells $[3,11,15,16]$. A precise mechanism of this action is not clear yet, but there are some lines of evidence indicating that arsenite greatly decreases the level of gluthathione causing the oxidative stress [17].

In our experiment we treated HEK293 cells with inductors of PBs, such as puromycin $(25 \mu \mathrm{g} / \mathrm{ml})$ and arsenite $(0.5 \mathrm{mM})$, and inhibitor of PBs - cycloheximide $(50 \mu \mathrm{g} / \mathrm{ml})$. After PBs induction or inhibition of PBs assembly we fixed HEK293 cells and stained them with anti-RCD-8 antibodies. According to the data presented in Fig. 5 (see inset) treatment of cells with PB inductors greatly increased the number and size of cell structures recognized with anti-RCD-8 antibodies and contrary, the treatment with inhibitor of PBs caused opposite effect. These data provide an additional evidence of anti-RCD-8 antibodies specificity.

Conclusions. In this study we obtained polyclonal antibodies that recognized RCD-8-component of PBs. We verified their specificity by Western blot, immunoprecipitation assay, and by immunofluorescence using known marker of PBs and conditions that promote their assembly/disassembly. In view of the absence of published data regarding regulation of $\mathrm{PB}$ dynamics by cell signaling pathways these antibodies could be a great tool to study these processes.

Acknowledgments. We thank Dr. V.Gorchev and Dr. S. Karahim for help with confocal studies.

\section{Д. О. Гудкова, Г. Г. Панасюк, І. О. Немазаний, В. В. Філоненко}

Нові антитіла проти RCD-8 як інструмент для вивчення процесивних тілець

\section{Резюме}

Мета. Розробити модельну систему для вивчення стану проиесивних тілець як можливого показника активності mTORкінази в клітинах ссавиів. Методи. Виділено поліклональні антитіла до одного з основних білків прочесивних тілеиь - RCD-8 із застосуванням методу імуноиитохімії. Результати. Показано, що отримані антитіла розпізнають внутрішньоклітинні структури, надалі ідентифіковані як прочесивні тільця. Білок, щьо детектується антитілами, локалізується разом з відомим маркером прочесивних тілець (DCPla) та частково - $з$ маркером стресових гранул (СРЕВ). Висновки. На основі даних щуодо зміни розмірів і кількості процесивних тілець у відповідь на обробку клітин відомими індукторами та інгібіторами утворення процесивних тілець доведено специфічність зазначених антитіл і підтверджено можливість їхнього використання для дослідження динаміки утворення процесивних тілецьь під контролем mTOR-залежного сигнального шляху.

Ключові слова: процесинг мРНК, декепінг, процесивні тільия, імуноцитохімія.

\section{Д. О. Гудкова, А. Г. Панасюк, И. А. Немазаный, В. В. Филоненко}

Новые антитела к RCD-8 как инструмент для изучения процессивных телец

Резюме

Цель. Разработать модельную систему для изучения состояния прочессивных телеи как возможного показателя активности mTOR-киназы в клетках млекопитающих. Методы. Выделены поликлональные антитела кодному из основных белков процессивных телец - RCD-8 с применением метода иммуночитохимии. Результаты. Показано, что полученные антитела узнают внутриклеточные структуры, идентифицированные далее как процессивные тельца. Детектируемый белоклокализуется вместе с известным маркером проиессивных телеи (DCP1a) и частично - с маркером стрессовых гранул (СРEB). Выводы. На основании данных об изменениях количества и размера процессивных телеи в ответ на обработку клеток известными индукторами и ингибиторами образования проиессивных телец продемонстрирована специфичность указанных антител и подтверждена возможность их использования для изучения динамики образования процессивных телец под контролем mTOR-зависимого сигнального пути.

Ключевые слова: прочессинг мРНК, декеппинг, прочессивные тельца, иммуноцитохимия.

\section{REFERENCES}

1. Coller J., Parker R. Eukaryotic mRNA decapping // Annu. Rev. Biochem.-2004.-73.-P. 861-890.

2. Cougot N., van Dijk E., Babajko S., Seraphin B. «Cap-tabolism» // Trends Biochem. Sci.-2004.-29, N 8.-P. 436-444.

3. Buchan J.R, Parker R. Eukaryotic stress granules: the ins and outs of translation // Mol. Cell.-2009.-36, N 6.-P. 932-941.

4. Wilusz C., Wormington M., Peltz S. The cap-to-tail guide to mRNA turnover // Nat. Revs Mol. Cell Biol.-2001.-2, N 4.P. 237-246.

5. Averous J., Proud C. G. When translation meets transformation: the mTOR story // Oncogene.-2006.-25, N 48.-P. 64236435.

6. Liu L., Li F., Cardelli J. A., Martin K. A., Blenis J., Huang S. Rapamycin inhibits cell motility by suppression of mTORmediated S6K1 and 4E-BP pathways // Oncogene.-2006.-25, N 53.-P. 7029-7070.

7. Sun S., Rosenberg L. M., Wang X., Zhou Z., Yue P., Fu H., Khuri F. R. Activation of akt and eIF4E survival pathways by rapamycin-mediated mammalian target of rapamycin inhibition // Cancer Res.-2005.-65, N 16.-P. 7052-7058. 
8. Stinton L. M., Eystathioy T., Selak S., Chan E. K., Fritzler M. $J$. Autoantibodies to protein transport and messenger RNA processing pathways: endosomes, lysosomes, Golgi complex, proteasomes, assemblyosomes, exosomes, and GW bodies // Clin. Immunol.-2004.-110, N 1.-P. 30-44.

9. Parker R., Sheth $U$. P bodies and the control of mRNA translation and degradation // Mol. Cell.-2007.-25, N 5.-P. 635646.

10. Garcia-Lozano J. R., Gonzales-Escribano M. F., Wichmann I., Nunez-Roldan A. Cytoplasmic detection of a novel protein containing a nuclear localization sequence by human autoantibodies // Clin. Exp. Immunol.-1997.-107, N 3.-P. 501506.

11. Yu J. H., Yang W.-H., Gulich T., Bloch K. D., Bloch D. Ge-1 is a central component of the mammalian cytoplasmic mRNA processing body // RNA.-2005.-11, N 12.-P. 1795-1802.

12. Bloch D. B., Gulick T., Bloch K. D., Yang W.-H. Processing body autoantibodies reconsidered // RNA.-2006.-12, N 5.P. 707-709.
13. Fenger-Gron M., Fillman C., Norrild B., Lykke-Andersen J. Multiple processing body factors and the ARE binding protein TTP activate mRNA decapping // Mol. Cell.-2005.-20, N 6.-P. 905-915.

14. Nemazanyy I., Breus O., Gout I., Filonenko V., Panasyuk G. Generation and characterization of monoclonal antibodies to mTOR kinase // Hybridoma.-2008.-27, N 5.-P. 395-399.

15. Wilczynska A., Aigueperse C., Kress M., Dautry F., Weil D The translational regulator CPEB1 provides a link between dcp1 bodies and stress granules // J. Cell Sci.-2005.-118, N 5.-P. 981-992.

16. Mollet S., Cougot N., Wilczynska A., Dautry F., Kress M., Bertrand E., Weil D. Translationally repressed mRNA transiently cycles through stress granules during stress // Mol. Biol. Cell.-2008.-19, N 10.-P. 4469-4479.

17. Cavigelli M., Li W., Lin A., Su B., Yoshioka K., Karin M. The tumor promoter arsenite stimulates AP-1 activity by inhibiting a JNK phosphatase // The EMBO J.-1996.-15, N 22.P. 6269-6279.

UDC 576.311.348

Received 12.08.10 